\title{
Assessment of Milk Production Competitiveness in Southern Areas of Tyumen Region
}

\author{
Svetlana M. Kayugina \\ FSBEI HE Northern Trans-Ural SAU \\ Tyumen, Russian Federation \\ kayugina@yandex.ru
}

\begin{abstract}
The paper identifies the main criteria defining the competitiveness of milk producers in the market. They include the level of marketability, selling price, cost, profitability, and quality of milk. The differentiation of southern areas of Tyumen region from the perspective of milk production competitiveness was carried out by clustering analysis in the Statistica program via the Ward's method. Five clusters are found on the basis of hierarchical classification. The mean cluster values are calculated and analyzed, thus resulting in the definition of the most competitive and noncompetitive areas of the region. The solution of the task related to competitiveness enhancement of dairy products in the south of Tyumen region requires certain measures connected with state support and innovations, which, if applied, will provide the region with high-quality and inexpensive milk according to scientifically grounded food standards.
\end{abstract}

Keywords - clustering analysis; dairy cattle breeding; competitiveness; profitability; economic efficiency; quality of milk.

\section{INTRODUCTION}

Competition is a rivalry between market participants for the best profit-gaining conditions. It is the most important market mechanism satisfying consumer needs and stimulating rise of production efficiency.

Competition and competitiveness as economic categories reflect the actual production efficiency of market participants, compare them, identify the strongest ones, and serve as a mechanism to control their market relations [1].

The study and synthesis of theoretical approaches to competitiveness allowed confirming that it is only possible to disclose its relevance with regard to certain objects of competitiveness (enterprise, product, industry, etc.).

On the one hand, the competitive capacity of an enterprise is the level of its scientific and technical, production, human resources, and marketing potential in production, and on the other hand, external social-economic and organizational factors that make it possible for the enterprise to create products at a more attractive price and under nonprice characteristics [2].

The competitive capacity of a product is the ability to meet the consumer demand in competitive conditions at affordable prices thus bringing high profit to producers in order to ensure reproduction on an expanded scale through intensive use of production resources [3].
The competitive capacity of an industry includes its ability for efficient introduction of innovations thus ensuring its leading positions among competitors towards the achievement of its business goals [2]

The competitiveness in modern business conditions shall define the potential of an enterprise to organize its activity efficiently taking into account the market environment and many other factors. It is critical for any enterprise to define its competitiveness for further design of its competitive strategy taking into account external and internal factors. The competitiveness as such shall reflect the advantages of a market participant, i.e. difference between competitors [4].

Milk production plays the leading role in the formation of a food fund in the south of Tyumen region. The consumption of milk and dairy products is a necessary condition of healthy nutrition, and the amount of milk produced in the region shall correspond to the level stipulated in the Russia's Food Security Doctrine.

At present, the dairy cattle breeding in the south of Tyumen region is stably reducing its milk production volumes. At the same time the market of milk and dairy products is expanding due to import from neighboring regions and Belarus, the competition between producers both inside the region and at the interregional level is growing. In such conditions further development of dairy cattle breeding and, moreover, the agricultural industry of the region in general depends on competitiveness enhancement of local dairy products.

\section{MATERIALS AND METHODS}

The scope of the study included factors defining competitiveness of dairy cattle breeding enterprises.

The subject of the study covered ninety agricultural enterprises of the south of Tyumen region dealing with milk production and sale within twenty-one municipal districts of the region.

The study utilized general scientific and special methods of knowledge, namely: economic analysis (to describe the current state of dairy cattle breeding in the region); graphical approach (to visualize the clustering of areas according to the level of competitiveness, to present statistical data); abstract and logical method (to provide theoretical grounds and make conclusions). The annual financial statements of agricultural 
enterprises of the south of Tyumen region were analyzed in Microsoft Excel. Normalization of basic data was carried out via computer processing in Statistica software, clustering analysis was conducted by the Ward's method.

\section{RESULTS AND DISCUSSION}

Modern economic development in the conditions of market economy and import substitution shall adhere to high-intensity level taking into account specifics of certain sectors of economy. The dairy cattle breeding industry is not an exception. The balanced and efficient use of all production resources and factors will allow approaching the level of food independence regarding milk and dairy products to values specified in the Russia's Food Security Doctrine and will foster the achievement of indicators stipulated by the state program of Tyumen region "Main development trends of agricultural industry for 2013-2020".

The dairy cattle breeding is one of the key branches of agricultural economy of the south of Tyumen region. The region provides itself with dairy products, however the recent years are characterized by the negative dynamics of industry indicators.

According to the Department of Federal State Statistics Service in Tyumen region, the milk production volume in 2016 has decreased by 59.7 thousand tons thus reaching the level of 2010. Milk production per capita for this period was reduced by $78 \mathrm{~kg}$ and made $90 \%$ of the rational standard (Fig. 1) $[5]$.

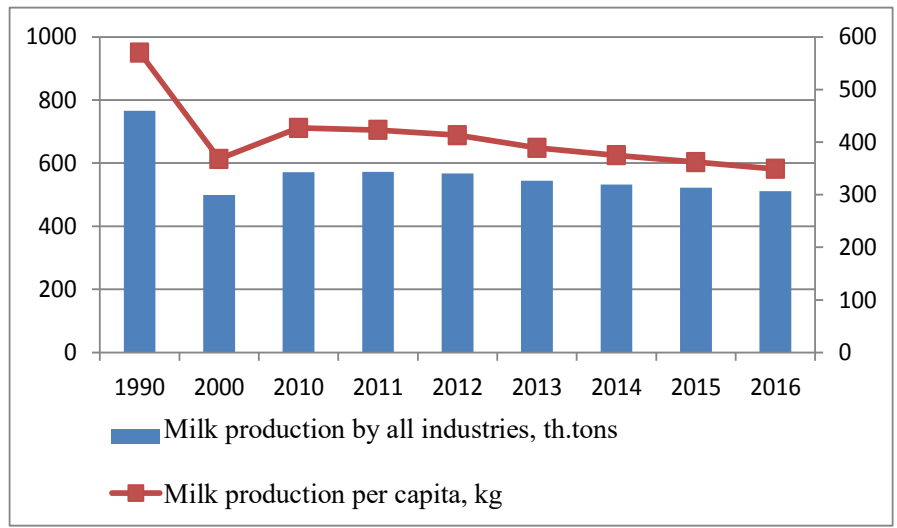

Fig. 1. Dynamics of milk production in the south of Tyumen region

The number of agricultural enterprises engaged in dairy cattle breeding is reducing each year. Such situation in this sector of agrarian economy may be caused by the product cost, low purchase prices of milk and shortage of skilled manpower. There is a discrimination on purchase prices for small and medium milk producers, which the dairy plants pay less than the large suppliers of raw milk. In some farms the milk production without subsidies hardly pays off or is even unprofitable thus preventing investments into this industry [6].

The problem of efficiency improvement and competitiveness enhancement of milk production requires complex assessment to define the level of competitiveness and develop the priority areas of its increase.

The assessment of competitiveness represents a complex multifactor task limited to identification of the most critical numerical indicators of competitiveness and their integration [7].

The cost reduction is considered a key aspect of milk production competitiveness enhancement. On average, feed costs make $45 \%$ of the milk cost in the region. The savings within this cost item are possible if milk producers are able to provide themselves with inexpensive and at the same time qualitative feed stocks since at present one third of all dairy feed is bought elsewhere. However, the feed savings shall not negatively influence the efficiency of dairy cow production and milk quality (fat and protein content) $[8,9]$.

The main criterion to assess the efficiency of any production, and, hence, the competitiveness, is the quality of products. Raw milk shall meet the requirements of current technical guidelines of the Customs Union "On safety of milk and dairy products" (TG CU 033/2013). The higher the quality of milk, the higher its purchase price.

Another competitiveness criterion is production distribution. Since milk production and sales have their specifics, then milk marketability and profitability of sales shall be used to assess such activity. The higher these criteria, the more efficient the sale and distribution [4].

The level of competitiveness of milk producers can be compared by calculating the index of competitiveness, which is defined by the relation of the level of profitability of milk sales in a given enterprise with the average level of profitability of milk sales in all studied enterprises. The use of the level of profitability of sales as a basis for calculating the index of competitiveness of milk production is explained by the fact that in modern economic conditions this indicator gives the most accurate estimates of production competitiveness in the market [2].

There is a need to identify certain groups among producers depending on the following parameters to assess the competitiveness of milk production in the south of Tyumen region:

$\mathrm{X} 1$ - index of competitiveness;

$\mathrm{X} 2$ - gross milk output, c;

X3 - milk sales volume, c;

X4 - marketability of milk, \%;

X5 - milk sales revenues, th.rub;

X6 - cost of sold milk, th.rub;

$\mathrm{X} 7$ - cost of $1 \mathrm{c}$ of milk, rub;

$\mathrm{X} 8$ - sale price of $1 \mathrm{c}$ of milk, rub;

X9 - profit (+), loss (-) on sales of $1 \mathrm{c}$ of milk, rub;

X10 - profitability (+), unprofitability (-) of milk sales, $\%$;

X11 - cost of purchased feed per 1 head of dairy herd, th.rub; 
$\mathrm{X} 12$ - share of costs for purchased feed, \%.

The clustering analysis was used to divide the areas of the south of Tyumen region into groups according to the level of milk production competitiveness. Unlike other statistical methods, for example, the grouping method, the clustering analysis allows classifying the objects not according to a single feature, but according to several indicators $[10,11,12]$.

Normalization of basic data was carried out via computer processing in Statistica software, clustering analysis was conducted by the Ward's method resulting in the dendrogram (Fig. 2).

Following the results of hierarchical classification five clusters are revealed within the studied set of indicators.

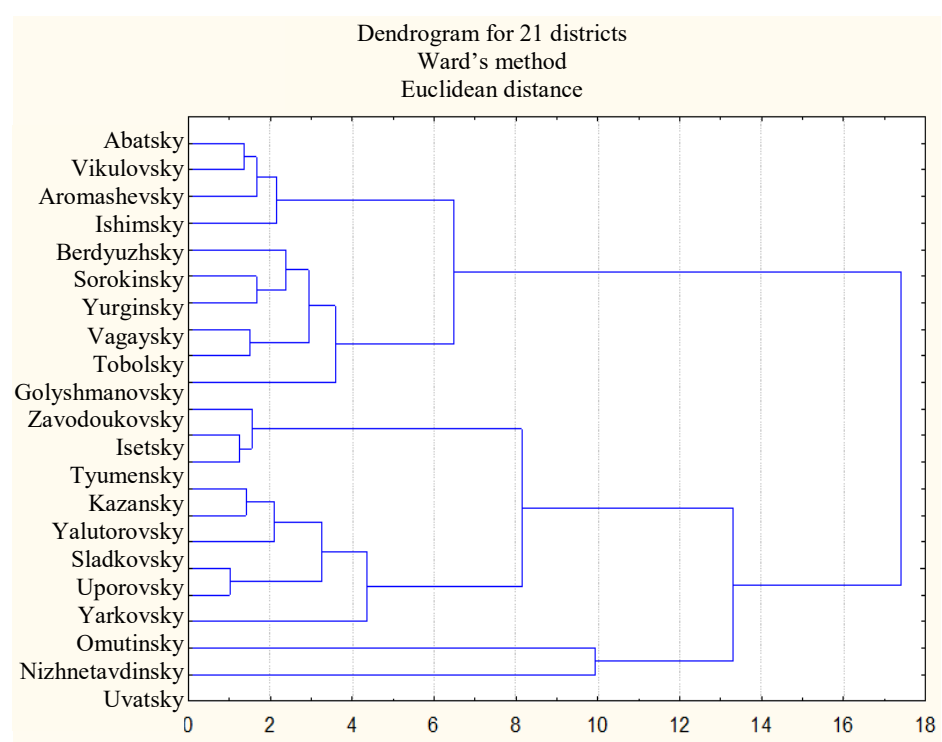

Fig. 2. Dendrogram of distribution of southern Tyumen regions into clusters

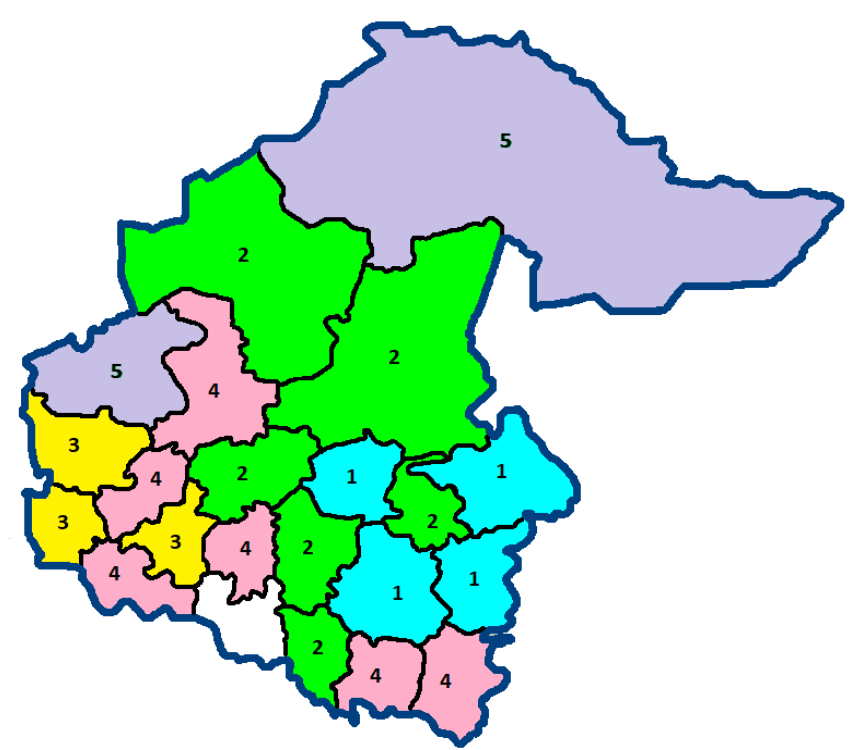

Figure 3 shows the territorial location of areas referring to the identified clusters. The map shows that clustering is not directly linked to agro-climatic zones of the south of Tyumen region.

The author calculated the average values for all considered indicators within each cluster (Table 1), which comparison and study made it possible to characterize the identified clusters.

The analysis of calculated average cluster indicators allows dividing the south of Tyumen region into areas with high and low competitiveness (Table 2).

TABLE 1. AVERAGE CLUSTERING VALUES

\begin{tabular}{|l|l|l|l|l|l|l|}
\hline \multirow{2}{*}{ Indicator } & \multicolumn{5}{|c|}{ Cluster } & \multicolumn{1}{c|}{$\begin{array}{c}\text { On } \\
\text { average }\end{array}$} \\
\cline { 2 - 7 } & \multicolumn{1}{|c|}{} & \multicolumn{1}{|c|}{$\mathbf{3}$} & \multicolumn{1}{|c|}{$\mathbf{4}$} & \multicolumn{1}{|c|}{5} \\
\hline Index of competitiveness & -0.13 & 1.14 & 1.12 & 1.64 & -0.19 & 1 \\
\hline Gross milk output, c & 48183 & 37572 & 367737 & 167634 & 101051 & 129966 \\
\hline Milk sales volume, c & 44316 & 30865 & 342535 & 156348 & 106579 & 121014 \\
\hline Marketability of milk, \% & 92 & 82 & 93 & 93 & 105 & 93 \\
\hline $\begin{array}{l}\text { Milk sales revenues, } \\
\text { th.rub. }\end{array}$ & 93480 & 64967 & 793196 & 353416 & 374619 & 286335 \\
\hline Cost of sold milk, th.rub. & 95372 & 55060 & 674195 & 280659 & 386526 & 247211 \\
\hline Cost of 1 c of milk, rub & 2152 & 1784 & 1968 & 1795 & 3627 & 2043 \\
\hline $\begin{array}{l}\text { Sale price of 1 c of milk, } \\
\text { rub }\end{array}$ & 2109 & 2105 & 2316 & 2261 & 3515 & 2366 \\
\hline $\begin{array}{l}\text { Profit (+), loss (-) on sales } \\
\text { of 1 c of milk, rub }\end{array}$ & -43 & 321 & 347 & 465 & -112 & 323 \\
\hline $\begin{array}{l}\text { Profitability (+), } \\
\text { unprofitability (-) of milk } \\
\text { sales, \% }\end{array}$ & -2.0 & 18.0 & 17.7 & 25.9 & -3.1 & 15.8 \\
\hline $\begin{array}{l}\text { Cost of purchased feed per } \\
\text { 1 head of dairy herd, th.rub }\end{array}$ & 4.85 & 2.41 & 18.13 & 18.52 & 37.32 & 18.07 \\
\hline $\begin{array}{l}\text { Share of costs for } \\
\text { purchased feed, \% }\end{array}$ & 15 & 9 & 27 & 38 & 42 & 33 \\
\hline
\end{tabular}

TABLE 2. DISTRIBUTION OF SOUTHERN TYUMEN REGIONS BY THE LEVEL OF COMPETITIVENESS OF DAIRY PRODUCTION

\begin{tabular}{|l|l|l|}
\hline $\begin{array}{c}\text { Level of } \\
\text { competitiveness }\end{array}$ & \multicolumn{1}{c|}{ Cluster } & \multicolumn{1}{c|}{ Region } \\
\hline High & 4 & $\begin{array}{l}\text { Kazansky, Yalutorovsky, Sladkovsky, Uporovsky, } \\
\text { Yarkovsky, Omutinsky }\end{array}$ \\
\hline Medium & 2,3 & $\begin{array}{l}\text { Berdyuzhsky, Sorokinsky, Yurginsky, Vagaysky, } \\
\text { Tobolsky, Golyshmanovsky, Zavodoukovsky, } \\
\text { Isetsky, Tyumensky }\end{array}$ \\
\hline Low & 1,5 & $\begin{array}{l}\text { Abatsky, Vikulovsky, Aromashevsky, Ishimsky, } \\
\text { Nizhnetavdinsky, Uvatsky }\end{array}$ \\
\hline
\end{tabular}

High level of competitiveness of dairy production is typical for six areas of the south of Tyumen region included into the fourth cluster. The level of profitability of milk sales within the cluster on average makes $25.9 \%$, which indicates the possibility of investments into this industry.

Nine areas of the region included into the second and third clusters have the medium level of competitiveness. The level of profitability of milk production in these clusters makes $18 \%$, which secures a profit not below the inflation rate and provides for simple reproduction.

Fig. 3. Distribution of southern Tyumen regions by clusters 
Six areas included into the first and fifth clusters have the negative profitability of milk sales and are thus characterized by low level of competitiveness.

Another important aspect is the number of agricultural enterprises within a cluster. This distribution is shown in Fig. 4.

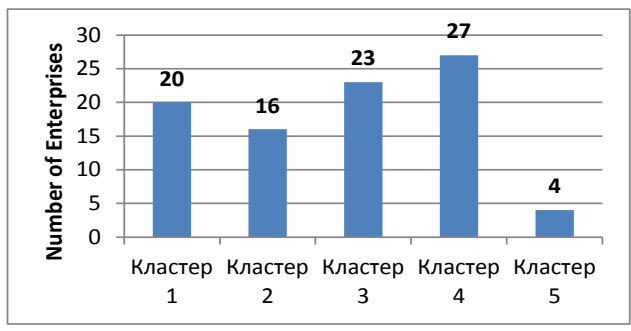

$\begin{array}{lllll}\text { Cluster } 1 & \text { Cluster } 2 & \text { Cluster } 3 & \text { Cluster } 4 & \text { Cluster } 5\end{array}$

Fig. 4. Distribution of agricultural enterprises by clusters

The fourth cluster is the largest and includes twenty-seven agricultural enterprises, which makes $30 \%$ of all enterprises engaged in dairy cattle breeding in the south of Tyumen region. The third cluster includes $26 \%$ of enterprises, the second $-18 \%$, the first $-22 \%$ and the fifth cluster $-4 \%$. As previously mentioned, the efficiency and competitiveness of milk production in the fourth cluster are higher compared to other clusters, thus, one third of milk producers in the region can be considered highly-competitive.

Regions of the first and the fifth clusters, which require the increase in efficiency and competitiveness of the industry, deserve the greatest attention. The specified areas have the necessary production facilities and food supply to ensure intensive dairy cattle breeding, however, require state funding, innovative and information technologies to increase the level of efficiency and competitiveness of their enterprises.

To solve the problems of dairy cattle breeding of the south of Tyumen region, the author proposed the following competitive development strategy:

- improvement of dairy cattle quality by enhancing the stock breeding;

- improvement of specific and graded feed crops and increase of their efficiency by introducing mineral and organic fertilizers, ensuring radical amelioration of natural forage lands;

- reduction of harvest losses due to advanced forage conservation technologies (haylage and silage in polymer packaging);

- increase of feed volumes instead of non-enriched grain, use of rolled grain in cow ration;

- use of innovative technologies for livestock handling, automation and computerization of livestock complexes, application of robotics for cow milking and feeding [13];

- improvement of dairy products distribution system;
- new forms of motivation and remuneration of staff engaged in dairy cattle breeding [14]

If implemented, the proposed measures will make it possible to raise the average annual milk yield, to increase milk quality, to reduce labor intensity and production cost thus ensuring the competitiveness enhancement of dairy-farming enterprises of the south of Tyumen region [15].

\section{CONCLUSIONS}

The competitiveness of dairy cattle breeding industry depends on two major factors: quality of production and its economic indicators. The prices of purchased raw materials are established by large milk processors depending on fat content, protein composition, grade, batch volume, seasonality and other conditions. The large producers using advanced innovative technologies are more competitive compared to small-scale dairy farms. One of the major economic parameters defining competitiveness of milk producers is the production cost. The agricultural organizations with extensive agricultural lands, personal mixed feed shops, advanced forage conservation technologies can save considerably on feeds and thus earn large profit from milk sales.

The analysis of economic indicators allowed dividing the south of Tyumen region into five clusters and identifying areas with high and low competitiveness. It is obvious that the least competitive areas require financial recovery and efficiency improvement first of all due to the increase of production volumes, improvement of milk quality and cost saving per unit cost.

The performed clustering analysis and the distribution of areas of the south of Tyumen region into groups will form a basis for more detailed study of problems related to the efficiency improvement and competitiveness enhancement of dairy cattle breeding and will provide for the differentiated approach and use of state support mechanisms.

The obtained results justify the reasons of using the clustering analysis as the tool to classify the areas of the region by competitiveness. The adequacy of results and usability of the method allow considering it as an adjunct to analytical methods used in any study.

\section{References}

[1] A.D. Rein, "Competitiveness of milk producers in Nizhny Novgorod Region", Proceedings of the International Scientific and Practical Conference of students and young scientists, "Problems and prospects of agrarian economy", Knyaginino, pp. 291-294, 2015.

[2] O.G. Afanasyeva, "Increase of dairy cattle breeding competitiveness in agricultural organizations", [extended abstract of Cand. Sci. (Economy) Dissertation, All-Russian Institute of Agrarian Problems and Informatics named after A.A. Nikonov, - Moscow, 2013].

[3] A.I. Kolobova, O.A. Kosintseva, "Competitiveness in milk production", Bulletin of Altai State Agricultural University, vol. 4 (66), pp.96-101 2010 .

[4] N.V. Denisova, O.A. Zubrenkova, A.D. Rein, M.V. Polyansky, "Determination of the competitiveness level of agricultural organizations within dairy cattle breeding", Management economic systems, 2015. vol. 9 (81), pp. 32

[5] Statistical yearbook: "Statistical yearbook of Tyumen region without autonomous areas", V. II, Department of Federal State Statistics Service 
in Tyumen region, Khanty-Mansi Autonomous District and YamaloNenets Autonomous District, Tyumen, 2017.

[6] S.M. Kayugina, "Clustering of southern Tyumen regions by milk production efficiency", Economy and business No. 8-3 (85-3), pp. 286289, 2017.

[7] K. V. Noskova, S.I. Batrakova, "Competitiveness of dairy cattle breeding of Sverdlovsk region", Agrarian science and education, No. 2, pp. 52, 2016.

[8] A.V. Sharopatova, "Assessment of competitiveness of dairy products in Krasnoyarsk Krai", Proceedings of the International Scientific and Practical Conference "Innovative Technologies in Economic and Social Processes of the Region", Krasnoyarsk, pp. 39-44, 2017.

[9] N.A. Polyanskaya, A.D. Rein, "Clustering of regions competitiveness and milk production efficiency" NSEEU Bulletin, Vol. 11 (54). 2015, pp. 79-85, A.D.

[10] S.M. Kayugina, "Retrospective analysis, current state and prospects of dairy production in the south of Tyumen region", Economy and business. vol. 9-1, pp. 265-268, 2017.
[11] O.I. Barinova, "Assessment of dairy cattle breeding efficiency using clustering method", Dairy and economic messenger, vol. 1 (5), pp. 60 67, 2012 .

[12] T.S. Rotar, "Cluster advantages in public administration of agricultural financial resources in the Sakha Republic (Yakutia)", Statistics and economy, V.14, vol. 5, pp. 14-22, 2017.

[13] D. Eremina, "IT-technologies in soil informatics and Russian agribusiness", [MATEC Web of Conferences 170, 04016 (2018) (URL: https://doi.org/10.1051/matecconf/201817004016)].

[14] N.G. Khairullina, O.V. Ustinova, G.V. Kuchterina, L.G. Agapitova, L.B Medvedeva, "Set of values in the structure of labor behavior of personnel”, Man in India, vol. 96(10), pp. 3957-3968, 2016.

[15] A.V. Kuznetsova, M.I. Krotov, "Comparative assessment of competitiveness of milk producing farms", Youth and science,. vol. 6, pp. 113, 2016. 